\section{ФОРМУВАННЯ КОНКУРЕНТОСПРОМОЖНОЇ МОДЕЛІ ПОРТУ}

\section{FORMATION OF A COMPETITIVE PORT MODEL}

\author{
КАЛІНІНА Г. Г., \\ кандидат економічних наук, \\ доцент, Азовський морський \\ інститут національного \\ університету «Одеська морська \\ академія", \\ РЯБЧУК В. В., \\ аспірант, Донецький державний \\ університет управління
}

\author{
KALININA A., \\ PhD in Economics, Associate \\ Professor, Azov Maritime Institute \\ National University "Odessa \\ Maritime Academy" \\ RIABCHUK V., \\ Post-graduate Student, \\ Donetsk State University of \\ Management
}

У статті на основі огляду літератури виділено чинники вибору порту. Доведено, чому виділені чинники впливають на конкурентоспроможність порту. Сформовано підгрунтя побудови моделі конкурентоспроможності порту.

Ключові слова: конкурентоспроможна модель, чинники вибору порту, портова інфраструктура, ланџюг поставок, корисність транспорту.

В статье на основе обзора литературы выделены факторы выбора порта. Доказано, почему выделенные факторы влияют на конкурентоспособность порта. Сформированы основы построения модели конкурентоспособности порта.

Ключевые слова: конкурентоспособная модель, факторы выбора порта, портовая инфраструктура, цепь поставок, полезность транспорта.

The article highlights the port selection factors based on a review of the literature. It is proved why the highlighted factors affect the competitiveness of the port. The basis for building a model of port competitiveness is formed.

Key words: competitive model, port selection factors, port infrastructure, supply chain, transport utility.

Постановка проблеми. За останні два десятиліття глобальний контейнерний транспорт швидко зріс, зокрема транспорт між Азією та Європою. Таке зростання контейнерних перевезень призвело до збільшення контейнерних терміналів та портів, найбільші з яких в цей час розташовані вздовж узбережжя Північного моря, в діапазоні Гамбург-Гавр. Простота поводження 3 контейнерами, як в портах, так і у внутрішніх перевезеннях, зробила їх набагато гнучкішими та еластичнішими за ціною. Це призвело до зменшення внутрішньої території для контейнерних портів й жорсткої конкуренції між ними.

На конкуренцію між контейнерними портами впливають різні фактори в секторі цих перевезень. Зміни факторів можуть мати значний вплив на порти та 
їх конкурентоспроможність. Основні зміни включають: збільшення розміру судна (що зменшує витрати на морський транспорт), глобальне потепління (що робить можливим використання Північного морського шляху в майбутньому) та невизначеність щодо мінливості цін на нафту. Вплив таких змін на конкурентоспроможність контейнерних портів важко оцінити та передбачити. Однак можна робити кількісні прогнози контейнерних потоків, щоб проаналізувати можливі наслідки різних змін на конкурентоспроможність порту.

Аналіз останніх досліджень та публікацій. Конкурентоспроможність морських портів досліджувалась у працях таких науковців, як: Робинсон Р. [1], Аронієтіс Р. [2], Уегманс Б. [3], Нотебум Т. [4], Тонгзон Дж. [6] та інші. У своїх працях вчені розглядали різні аспекти цього явища, але подальше зростання активності на ринку морських перевезень потребує нових методів, підходів до вивчення моделей конкурентоспроможної поведінки.

Метою статті $\epsilon$ дослідження чинників вибору порту, як складових моделі його конкурентоспроможності.

Виклад основного матеріалу дослідження. Якщо контейнерні потоки можна передбачити, тобто змоделювати, тоді вплив різних політик, інвестицій та сценаріїв можна кількісно оцінити та проаналізувати.3 цією метою дослідниками було проаналізовано 31 порт, це переважно великі контейнерні порти, враховуючи їх пропускну здатність. Деякі менші порти також включені, щоб отримати добре географічне охоплення материкової частини Свропи. Для цього дослідження вивчався імпорт контейнерів з Азії на материкову частину Свропи. Потік контейнерів 3 Азії $\epsilon$ найбільшим потоком і зростав швидкими темпами. Європа імпортує з Азії більше продукції, ніж експортує, тому розмір контейнерного імпорту є нормативним. Це означає, що фактори, що стосуються експортних потоків, що впливають на конкуренцію в порту, не включені в дослідження.

Конкурентоспроможний порт вибирається частіше, чим навпаки. Отже, конкуренція порту часто моделюється як проблема вибору порту. Розглядаючи вибір порту, слід враховувати повний транспортний ланцюг. Частіше обирається порт, який вбудований у найбільш (сприятливі) транспортні ланцюги. Розгляд літератури щодо вибору порту надав детальний огляд важливих факторів вибору порту. 3 цього огляду обрано дванадцять факторів вибору порту: морські витрати, витрати на внутрішні території, портові витрати, час на морському транспорті, час на перевезення, час перебування в порту, кількість заходів у морські порти, кількість коротких морських відправників, глибина води (частина портової інфраструктури), кількість відправників внутрішніх водних шляхів, кількість відправників залізничного транспорту та попит на контейнери. Ці фактори переважно вибираються через те, що вони найчастіше згадуються як ключові фактори особами, що приймають рішення щодо вибору порту, вантажовідправниками, експедиторами та судноплавними лініями. Далі для цілей моделювання важливо використовувати кількісні фактори, які застосовуються для вибору порту та не є специфічними для вибору терміналу. Загальнодоступні та порівнянні дані щодо цих факторів можна знайти для кожного з 31 портів. 
У відповідності до цих названих факторів вибір порту можна змоделювати. Це робиться за допомогою широко застосовуваної багаточисельної моделі дискретного вибору, що використовується для моделювання вибору маршруту. Цей метод далі використовується для визначення ймовірності вибору маршруту на основі корисності маршруту порівняно 3 корисністю альтернативних маршрутів. Імовірність маршруту трактується як ринкова частка цього маршруту. Корисність визначається як лінійна функція факторів вибору порту з відповідними вагами та базується на теорії мікроекономічної корисності. Ця теорія стверджує, що людина завжди вибере варіант 3 найбільшою корисністю. Маршрут включає повний транспортний ланцюг і складається з: морського транспорту з Азії до Європи (включаючи фідерний транспорт), перевалки в порту та внутрішнього транспорту до кінцевого пункту призначення. Для внутрішнього транспорту можуть використовуватися автомобільні, залізничні та внутрішні водні шляхи. Порт, який часто вибирають для регіону, отримає більшу частку ринку, і тому вважається більш конкурентоспроможним, ніж порт, який вибирають рідше. Отже, вивчення портової конкуренції означає визначення факторів, що впливають на вибір порту. Необхідно провести аналіз різних факторів, що впливають на вибір порту. На вибір порту впливають особливості транспортного ланцюга та учасники цього транспортного ланцюга.

Згідно з Робинсоном Р. [1], порти слід розглядати не як єдине ціле, а як частину та вбудовувати в ланцюжок створення вартості. Тому, розглядаючи вибір порту, необхідно дослідити повний ланцюг поставок і вибрати найкращий 3 можливих. Вибирається той порт, який вбудований у більшість ланцюгів поставок. 3 цього часу це визначення було прийняте багатьма. Однак, оскільки ланцюги поставок різні для кожної компанії, аналіз ланцюгів поставок неможливий, тому аналізуються транспортні ланцюги, якими виступає ланцюжок поставок.

Транспортні ланцюги складаються з різних ланок, які представляють різні види діяльності та різних суб'єктів. Транспортний ланцюг показує всі основні заходи з перевезення вантажу від місця його походження до місця призначення. Ці заходи включають передміський транспорт, перевезення контейнерів у порт відправлення, морський транспорт, перевезення контейнерів у порту призначення та внутрішні перевезення. Ці види діяльності можна розділити на два типи - перевезення та перевантаження. Перевезення - це діяльність 3 переміщення товару, в даному випадку контейнера, 3 одного місця в інше. Перевантаження - це діяльність 3 переміщення контейнера між видами транспорту або в/з складу або буфера. Для всіх цих заходів задіяні різні суб'єкти. Передбачається, що походженням транспортного ланцюга $є$ Азія, а пунктом призначення $є$ регіон на материковій частині Європи. Морський транспорт здійснюється глибоководними суднами, а внутрішній транспорт здійснюється вантажівками, поїздами та баржами. Перевантаження здійснюється на контейнерних терміналах, які знаходяться в портах, перевалка у внутрішніх районах може здійснюватися на менших внутрішніх терміналах.

Перша частина ланцюга (початок до порту завантаження контейнерів) не буде врахована, відправною точкою буде морська транспортна ланка. Тому 
враховується лише один глибоководний порт, в даному випадку порт на материковій частині Європи.

Фактори вибору порту. Різні сегменти відіграють певну роль у різних частинах транспортного ланцюга. До них належать; вантажовідправники, стивідори, оператори терміналів, портові адміністрації, судноплавні компанії, експедитори, сторонні постачальники логістичних послуг, транспортні компанії та інші [1]. Однак кількість учасників, які роблять вибір порту, набагато менша. У літературі особливо вивчалася роль вантажовідправників, експедиторів та транспортних ліній. Вони визначені ключовими особами, що приймають рішення щодо вибору порту. Ролі операторів терміналів, постачальників логістичних послуг, портових адміністрацій та урядів щодо вибору порту були досліджені в обмеженій кількості робіт [2].

Лінії доставки. Основні транспортні лінії набули сили прийняття рішень, оскільки їх частка на ринку зросла, а кількість гравців зменшилась. Багато перевізників розширили свою бізнес-модель, об'єднавшись 3 операторами терміналів, створивши спеціальні термінали.

Це стало можливим завдяки консолідації, відбулася вертикальна та горизонтальна інтеграція між операторами та операторами терміналів. Це призвело до дуже високої частки ринку лише для декількох основних груп. Ї̈ сила зросла завдяки злиттю та об'єднанням $[3,4]$. Нині три найбільші перевізники Maersk, MSC та CMA CGM планують створити новий альянс під назвою Р3 [4]. Це ще більше зміцнить їхні позиції щодо своїх конкурентів. Цей союз міг би стати настільки домінуючим гравцем, що він міг би потенційно зловживати своєю ринковою владою та, наприклад, вести переговори про нижчі портові збори. Лінії судноплавства зараз розглядаються як основний орган, який приймає рішення щодо вибору порту [2].

Для судноплавних ліній були знайдені такі фактори вибору: портові витрати, портова інфраструктура, портові послуги та час повороту, розташування на ринку внутрішніх територій, вантажна база, підключення до фідерів та наявність внутрішніх сполучень [2, 3, 4, 6, 7]. Ці фактори значною мірою орієнтовані на порти і менш залежать від транспортного ланцюга.

Вантажовідправники та експедитори. Вантажовідправники або одержувачі $\epsilon$ власниками вантажу і оплачують транспорт. Їх цікавлять тарифи перевізників та витрати на обслуговування терміналу, а також час транспортування вантажу. Експедитори або агенти організовують транспорт і наймають транспортні компанії для перевезення вантажу; вони приймають практичні транспортні рішення. Їх інтереси полягають у пошуку найкращого (доступного за ціною) рішення для своїх клієнтів, і вони можуть згрупувати вантаж, щоб отримати ефекти консолідації. Для вантажовідправників та експедиторів важливими $є$ такі фактори: частота обслуговування глибоководних суден, вартість порту, географічне розташування, ефективність порту та надійність порту $[6,7,8]$.

Ці фактори також дуже орієнтовані на порти і менше стосуються ланцюга поставок. Загальний час транспортування конкретно не згадувався, а загальні витрати - лише кілька разів. Це несподівано, оскільки витрати виявляються найважливішим фактором [2], а часом домінуючим фактором у виборі 
океанічного носія [4]. Однак це також може означати, що деякі фактори витрат і часу важливіші за інші.

Порти та термінали. Порти в більшості випадків перебувають у державній власності і ними керує орган порту. Очевидно, що порти не приймають рішення щодо вибору порту для контейнерних перевезень, але оцінюють фактори вибору порту своїх клієнтів. Їх клієнтами $\epsilon$ контейнерні термінали, які часто перебувають у приватній власності та відповідають за обробку контейнерів. Термінали, як правило, мають довгострокові контракти і не часто змінюють порти, однак, коли інші порти є більш привабливими, вони розглянуть можливість інвестування в інший порт. Тому фактори вибору порту для терміналів є важливими для портових органів.

Отже, в основному $є$ три фактори, які впливають на конкурентоспроможність порту: морський доступ, зв'язок 3 фідерним транспортом та внутрішні послуги. Морський доступ включає глибину води порту та його здатність приймати великі судна. Транспортне підключення фідера описує кількість з'єднань, які порт має 3 іншими портами, це важливо для функції концентратора або функції перевантаження порта. Кількість внутрішніх служб включає кількість інтермодальних послуг та частот та наявну інфраструктуру. Це важливо для контейнерного імпорту, який потрібно транспортувати до місця призначення у глибинці.

Сторонній постачальник логістики. Сторонні постачальники логістичних послуг управляють повним ланцюгом поставок для своїх клієнтів, тоді як експедитори організовують лише перевезення вантажів. Ланцюг поставок включає перевезення вантажів, а також зберігання та складування вантажів. Контейнерні термінали, розташовані в порту, є частиною ланцюга поставок, тому фактори ланцюга поставок та фактори транспортної логістики відіграють певну роль у виборі порту. Ця терміналізація ланцюга поставок [4] фактично означає, що термінали інтегровані у весь ланцюг поставок і можуть також виконувати функції буферів у ланцюгу поставок. Це показує потенціал терміналів як транспортно-логістичних центрів.

Виявлено різні фактори логістики та ланцюга поставок: загальні витрати, загальний час транспортування, загальна відстань, витрати на трубопроводи, надійність часу, щільність вантажу, розмір вантажу, розмір попиту на вантаж та наявність / кількість сполучень 3 внутрішніми районами.

Фактори вибору порту, згадані учасниками, упорядковані відповідно до їхнього становища в транспортному ланцюзі. Морський транспорт та внутрішній транспорт вказують на транспорт між місцями походження, пунктами призначення та портами. Характеристики порту дають інформацію про порівняльну конкурентоспроможність окремих портів.

Коефіцієнт «ефективність порту» використовується для визначення того, наскільки ефективним $є$ порт при обробці контейнерів. Це стосується факторів «надійність порту» та «портові послуги», але воно є більш кількісним, оскільки його можна виміряти за допомогою моделей введення-виведення. Були проведені дослідження для розрахунку максимальної ефективності портів 3 використанням прикордонних та огороджувальних методів. Якість обробки контейнерів у порту здебільшого залежить від якості терміналу. Сюди входить вантажопідйомність крана та продуктивність праці. На старих терміналах може 
не вистачати потужності крана, і продуктивність праці значною мірою залежить від страйків профспілок.

Висновки $і$ перспективи подальших досліджень. У цьому дослідженні конкурентоспроможність порту визначається шляхом моделювання вибору порту. Вибір порту $\epsilon$ частиною вибору маршруту. Для вибору маршруту використовується широко застосовувана багаточисельна модель дискретного вибору. У транспортному моделюванні прибутковість чи корисність транспорту визначається як корисність. Корисність визначається як лінійна функція факторів вибору порту 3 відповідними вагами та базується на теорії мікроекономічної корисності. Ця теорія стверджує, що людина завжди вибере варіант $з$ найбільшою корисністю.

Розгляд літератури щодо вибору порту надав детальний огляд важливих факторів вибору порту. 3 нього відібрано дванадцять факторів вибору порту: морські витрати, витрати на внутрішні райони, портові витрати, час на морському транспорті, час на перевезення у глибину, час перебування в порту, кількість виходів у порти в глибоководний порт, кількість коротких морських служб, кількість служб внутрішніх водних шляхів, кількість залізничних послуг та попит на контейнери. Ці фактори в першу чергу вибираються через те, що вони згадуються ключовими особами, що приймають рішення щодо вибору порту, вантажовідправниками, експедиторами та судноплавними лініями.

\section{References:}

1. Robinson R. Ports as elements in value-driven chain systems: the new paradigm. Maritime Policy \& Management. 2002. 29, pp. 241-255.

2. Aronietis R., Van de Voorde E. \& Vanelslander T. Competitiveness determinants of some European ports in the containerized cargo market. BIVEC/GIBET Transport Research Day. 2011.

3. Wiegmans B., Hoest A., Notteboom T. Port and terminal selection by deepsea container operators. Maritime Policy \& Management. 2008. 35, pp. 517-534.

4. Notteboom T., Winkelmans W. Structural changes in logistics: how will port authorities face the challenge? Maritime Policy \& Management. 2001. 28, pp. 71-89.

5. Dagblad-transport. 2013. Maersk, MSC en CMA CGM samen in P3 netwerk van 2,6 miljoen teu. URL: http://www.dagbladtransport.nl/maersk-mscencma-cgm-samen-in-p3-netwerk-van-26-miljoen-teu.

6. Tongzon J. \& Sawant L. Port choice in a competitive environment: from the shipping lines' perspective. Applied Economics. 2007. 39, pp. 477-492.

7. Karlaftis M., Kepaptsoglou K. \& Sambracos E. Containership routing with time deadlines and simultaneous deliveries and pick-ups. Transportation Research Part E: Logistics and Transportation Review. 2009. 45, pp. 210-221.

8. Malchow M., Kanafani A. A disaggregate analysis of port selection. Transportation Research Part E: Logistics and Transportation Review. 2004. 40, pp. 317-337.

A review of the port selection literature provided a detailed overview of important port selection factors. The twelve factors of port selection were selected 
from it: sea costs, inland costs, port costs, time on sea transport, time for deep transportation, time in port, number of exits to ports in deep port, number of short sea services, water depth (part of port infrastructure), number of inland waterway services, number of railway services and demand for containers.

These factors are chosen primarily because they are mentioned by key port decision makers, shippers, freight forwarders and shipping lines. Second, for simulation purposes, it is important to use quantitative factors that are used for port selection and are not specific to terminal selection. Third, publicly available and comparable data on these factors were found for all 31 ports.

For modeling purposes, port selection factors must be quantified, so only quantifiable port selection factors are included. In some cases, this means that the factor will not be included in this study, in other cases, the factor is divided into smaller subfactors. Another factor is the availability of reliable and comparable data on factors. The analysis by factor is given; the selected factors for the model are presented in the figure.

In this study, port competitiveness is determined by modeling port selection. Port selection is part of route selection. The widely used multiple model of discrete logit selection is used for route selection. This method determines the probability of route selection based on the usefulness of the route compared to the usefulness of alternative routes. The probability of a route is interpreted as the market share of this route.

In transport modeling, the profitability or usefulness of transport is defined as utility. Utility is defined as a linear function of port selection factors with appropriate weights and is based on the theory of microeconomic utility. This theory states that a person will always choose the option that is most useful. 